\title{
Not all is lost: journey of a deep periorbital burn
}

\author{
Swati Singh, ${ }^{1}$ Purvasha Narang, ${ }^{1}$ Ankur Sood, ${ }^{2}$ Vikas Mittal ${ }^{1}$
}

${ }^{1}$ Ophthalmic Plastics Surgery and Cornea Services, LJ Eye Institute, Ambala, Haryana, India ${ }^{2}$ Plastics Surgery, Tricity Institute of Plastics Surgery, Chandigarh, India

\section{Correspondence to Dr Vikas Mittal, \\ vikas_mittal@hotmail.com}

Accepted 4 August 2017

\section{CrossMark}

To cite: Singh $S$, Narang $P$, Sood A, et al. BMJ Case Rep Published Online First: [please include Day Month Year]. doi:10.1136/bcr-2017221565

\section{DESCRIPTION}

A 16-year-old male presented with deep dermal burns of upper and lower eyelids and decreased vision in left eye after falling on a hot silencer of a motorcycle 2 weeks before. His best-corrected visual acuity was $6 / 6$ and light perception in right and left eye, respectively. Skin over the left side of the nose, root of the nose and right medial brow area was necrotic extending up to submusculoaponeurotic layer (figure 1A). There was localised corneal perforation inferiorly with iris prolapse and shallow anterior chamber in left eye. Urgent debridement was performed under general anaesthesia. Necrosis was involving tarsal plates in both the eyelids. Corneal perforation was sealed with cyanoacrylate glue along with permanent tarsorrhaphy to prevent exposure keratopathy. Three weeks later, eyelid was reconstructed with split thickness skin graft harvested from right anterolateral thigh along with paramedian forehead musculocutaneous flap (figure 1B). Corneal melt was still worsening due to loss of orbicularis function, which required blepharorrhaphy. Corneal melt healed with adherent leucoma and quiet ocular surface could be attained after 2 months from injury (figure 2A). Residual lagophthalmos was fixed with retroauricular full thickness skin grafting in upper and lower eyelids (figure 2B). Successful visual rehabilitation (6/18 in left eye) could be accomplished by full thickness keratoplasty combined with cataract extraction and intraocular lens replacement at 8 months from injury (figure $2 \mathrm{C}, \mathrm{D}$ ).

Primary aim in periorbital burn with ocular involvement lies in salvaging eye followed by vision. ${ }^{12}$ Burn scar management in late stages requires eyelid reconstruction with free flaps or skin grafting to restore functional anatomy. ${ }^{3}$ Adequate corneal coverage in acute phase should be aimed in

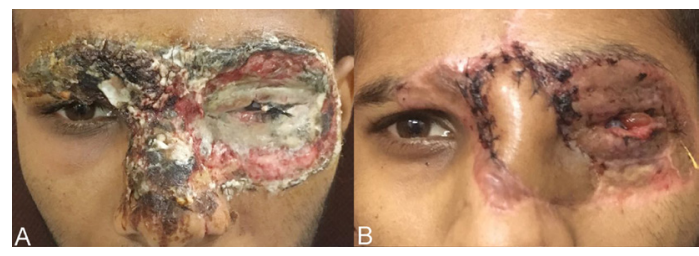

Figure 1 (A) At presentation, deep dermal burn involving upper and lower eyelid, left side of nose and contralateral medial brow. (B) Status after periocular reconstruction with split thickness skin grafting and paramedian forehead flap.

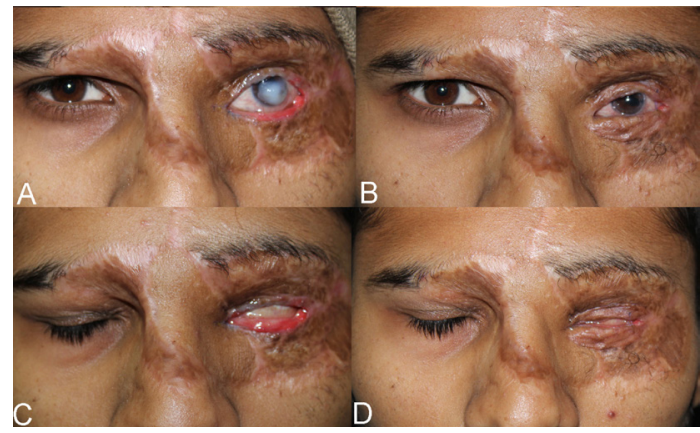

Figure 2 (A) Corneal scarring with exposure keratopathy after blepharorrhaphy release. (B) Residual lagophthalmos repaired with skin grafting followed by penetrating keratoplasty in left eye. (C, D) Lagophthalmos before and after postauricular skin grafting.

order to prevent worsening of exposure keratopathy. This case highlights the importance of an early intervention and management outcome as a result of multidisciplinary approach.

\section{Learning points}

Adequate corneal protection in acute setting of thermal burn might require complete blepharorrhaphy.

- Vision salvage can be achieved in cases with extensive periorbital burns under multidisciplinary care.

Contributors SS was responsible for the drafting and final editing of manuscript and clinical management. PN was responsible for the literature review. AS was responsible for the clinical management.

VM was involved in the editing of the manuscrip and clinical management.

Competing interests None declared.

\section{Patient consent Obtained.}

Provenance and peer review Not commissioned; externally peer reviewed.

(c) BMJ Publishing Group Ltd (unless otherwise stated in the text of the article) 2017. All rights reserved. No commercial use is permitted unless otherwise expressly granted.

\section{REFERENCES}

1 Fitzgerald O'Connor E, Frew Q, Din A, et al. Periorbital burns - a 6 year review of management and outcome. Burns 2015;41:616-23.

2 Malhotra R, Sheikh I, Dheansa B. The management of eyelid burns. Surv Ophthalmol 2009;54:356-71.

3 Hayashida K, Akita S. Surgical treatment algorithms for post-burn contractures. Burns Trauma 2017:5:9. 
Copyright 2017 BMJ Publishing Group. All rights reserved. For permission to reuse any of this content visit http://group.bmj.com/group/rights-licensing/permissions.

BMJ Case Report Fellows may re-use this article for personal use and teaching without any further permission.

Become a Fellow of BMJ Case Reports today and you can:

- Submit as many cases as you like

- Enjoy fast sympathetic peer review and rapid publication of accepted articles

Access all the published articles

- Re-use any of the published material for personal use and teaching without further permission

For information on Institutional Fellowships contact consortiasales@bmjgroup.com

Visit casereports.bmj.com for more articles like this and to become a Fellow 